\title{
Construction and analysis of the transgenic carrot and celery plants expressing the recombinant thaumatin II protein
}

\author{
Yu. S. Luchakivska ${ }^{1}$ I. K. Komarnytskii ${ }^{1}$, I. M. Kurchenko², \\ O. M. Yurieva², N. V Zhytkevich², M.V. Kuchuk ${ }^{1}$ \\ ${ }^{1}$ Institute of Cell Biology and Genetic Engineering, NAS of Ukraine \\ 148, Akademika Zabolotnoho Str., Kyiv, Ukraine, 03680 \\ ${ }^{2}$ D. K. Zabolotny Institute of Microbiology and Virology, NAS of Ukraine \\ 154, Akademika Zabolotnoho Str., Kyiv, Ukraine, 03680 \\ yu.luchakivskaya@gmail.com
}

\begin{abstract}
Aim To obtain the transgenic carrot and celery plants able to express recombinant thaumatin II in order to increase plant stress tolerance. Methods. Agrobacterium-mediated transformation of carrot and celery seedlings was used for obtaining the transgenic plants. Presence and transcription of the transgene in plant tissues were proved by PCR and RT-PCR analysis. The plants were tested for biotic stress tolerance by in vitro antifungal and antibacterial activity assays and for salinity and osmotic stress tolerance by plant survival test in presence of $\mathrm{NaCl}$ and PEG in different concentrations. Results. Transgenic plants able to express recombinant thaumatin II gene (transcription proved for 60-100\%) were obtained by agrobacterial transformation. The transgenic carrot plant extracts inhibited growth of the studied phytopathogenic bacteria strains but exhibited no antifungal activity. Survival level of transgenic plants under the salinity and osmotic stress effect was definitely higher comparing to the untransgenic ones. The analysis of photosynthetic pigment content in the transgenic carrot plants showed no significant difference of this parameter under salinity stress that may indicate the possible protective activity of the recombinant protein. Conclusions. The obtained in our study transgenic carrot and celery plants able to express the recombinant thaumatin II gene were characterized by antibacterial activity and increased tolerance to salinity and osmotic stress factors.
\end{abstract}

Keywords: carrot, celery, thaumatin II, Agrobacterium-mediated transformation, stress tolerance.

\section{Introduction}

Such environmental stresses as soil salinity, drought and pathogen infection are considered the most harmful ones that can severely limit the plant growth and productivity [1]. Nowadays the transgenic approaches are successfully used for creation of the crops with over-expression of the genes that encode specific defensive proteins which are induced in response to different types of stress and pathogen attack. Recent studies have shown the enhanced plant abiotic stress tolerance in addition to plant resistance to fungal pathogens for the transgenic plants carrying the recombinant thaumatin gene [2-4]. Thaumatin is a sweet-tasting protein isolated from Thaumatococcus daniellii (Benth) fruits and known for its strong homology to thaumatin-like defensive proteins that are considered to alter the membrane permeability and the cell signal transduction cascades in plants and fungi as a result of stress or pathogen infection [2, 5]. Here we report the obtaining of transgenic carrot and celery plants able to express the recombinant gene of thaumatin II protein. The antibacterial and antifungal in vitro assays were carried out in order to find out whether this gene expression supports the resistance of the obtained transgenic crops to patho-

(C) 2015 Yu. Luchakivska et al.; Published by the Institute of Molecular Biology and Genetics, NAS of Ukraine on behalf of Biopolymers and Cell. This is an Open Access article distributed under the terms of the Creative Commons Attribution License (http://creativecommons.org/licenses/by/4.0/), which permits unrestricted reuse, distribution, and reproduction in any medium, provided the original work is properly cited 
gen infection. The plant testing for in vitro osmotic and salt stress resistance enabled the identification of the plant lines able to develop and generate biomass under stress conditions.

\section{Materials and Methods}

Plant material. Aseptic carrot plants cv. Nantska, Korotel, Red Giant and Perfektziya and celery ones cv. Paskal, Zephyr, Yablochnyi were used for our study. The seeds of carrot crop lines Konservna-2, Dobir-1, Dobir-4 were generously provided by the Institute of Vegetable- and Melon-growing, NAAS of Ukraine. Seeds were surface-sterilized by dipping in $70 \%$ ethanol for $2 \mathrm{~min}$ followed by $2 \%$ sodium hypochlorite for $15 \mathrm{~min}$ and rinsing four-times in sterile distilled water. The carrot and celery seeds were germinated on MS medium [6] for 10-14 days.

\section{Binary vectors and bacterial strains}

The plasmid vectors pCB171 and pCB169 contained the sequence coding for recombinant thaumatin II gene fused with plastid targeting transit peptide sequence driven by $35 S$ CaMV promoter and the selective genes of neomycin phosphotransferase II (nptII) and phosphinothricin $\mathrm{N}$-acetyltransferase (bar) respectively driven by nopaline synthase (nos) promoter $[7,8]$. Both constructs were transferred to Agrobacterium tumefaciens nopaline strain GV3101 and Agrobacterium rhizogenes agropine strain A4 and then used for the plant genetic transformation. The bacterial suspension was cultured over night in liquid LB medium (10 g/1 hydrolyzate casein, $5 \mathrm{~g} / 1$ yeast extract, $10 \mathrm{~g} / 1 \mathrm{NaCl}, \mathrm{pH} 7.2$ ) at $28^{\circ} \mathrm{C}$ on rotary shaker $(200 \mathrm{rpm})$ with $50 \mathrm{mg} / \mathrm{l}$ carbenicillin for both bacteria species and additionally $50 \mathrm{mg} / 1$ rifampicin for A. tumefaciens.

\section{Genetic transformation}

The bacterial suspension culture was sedimented by centrifugation $\left(4,000 \mathrm{rpm}, 4^{\circ} \mathrm{C}\right)$. We used liquid MS medium with $200 \mu \mathrm{M}$ acetosyringone for resuspendation of the obtained sediment with its further cultivation on rotary shaker $(200 \mathrm{rpm})$ at $28{ }^{\circ} \mathrm{C}$ for $1 \mathrm{~h}$. The plantlets were inoculated with the obtained bacterial culture by vacuum infiltration. Then they were incubated on sterile blotting paper for $48 \mathrm{~h}$ in scattered day light.

The inoculated carrot explants were cultivated on MS medium with $2 \mathrm{mg} / 1$ Dicamba to stimulate callus forming, with $100 \mathrm{mg} / \mathrm{l} \mathrm{kanamycin} \mathrm{as} \mathrm{selective} \mathrm{agent}$ and $500 \mathrm{mg} / \mathrm{l}$ cefotaxim for bacterium elimination. In 5-6 weeks the primary carrot callus clones were put on hormone-free MS medium with the antibiotics of mentioned concentrations and were cultivated for 3-4 months at $22-23{ }^{\circ} \mathrm{C}, 16$-hour-period lighting for regeneration. In 4-5 weeks the obtained celery callus clones were transferred to B5 medium [9] with $0.1 \mathrm{mg} / \mathrm{l}$ naphthaleneacetic acid and $0.6 \mathrm{mg} / \mathrm{l} \mathrm{kinetin}$ for plant regeneration, $600 \mathrm{mg} / \mathrm{l}$ cefotaxim and $5 \mathrm{mg} / \mathrm{l}$ Basta or $100 \mathrm{mg} / \mathrm{l}$ kanamycin as selective agents. The obtained plants were moved to glass tubes and then rooted in MS medium.

\section{Molecular analysis of the transgenic plants}

PCR The total plant DNA was extracted by CTABmethod [10]. The total agrobacterial DNA was extracted according to Draper et al. [11]. The transgene presence in the obtained plants was proved by PCR analysis. The analysis was carried out using 5 'gcatg cccaccttcgagatcg $3^{\prime}$ и $5^{\text {'gcttgcatgcctctagactgcagtt3 }}{ }^{\prime}$ primers for amplification of $642 \mathrm{bp}$ thaumatin gene fragment under such conditions: $5 \mathrm{~min}$ at $94^{\circ} \mathrm{C}-30$ cycles $\left(30\right.$ s at $94^{\circ} \mathrm{C} ; 30$ s at $68^{\circ} \mathrm{C} ; 45 \mathrm{~s}$ at $\left.72^{\circ} \mathrm{C}\right)-5 \mathrm{~min}$ at $72{ }^{\circ} \mathrm{C}$. To detect bacterial contamination we applied primer pair 5' -atgtcgcaaggcagtaagccca-3', 5' -ggagtc tttcagcatggagcaa-3'[12] for amplification of $432 \mathrm{bp}$ fragment of virD1 gene under the following conditions: 5 min at $94{ }^{\circ} \mathrm{C}-30$ cycles $\left(30\right.$ s at $94{ }^{\circ} \mathrm{C} ; 30 \mathrm{~s}$ at $60{ }^{\circ} \mathrm{C} ; 30 \mathrm{~s}$ at $72{ }^{\circ} \mathrm{C}$ ) $-5 \mathrm{~min}$ at $72{ }^{\circ} \mathrm{C}$. The samples were fractionated in $1 \%$ agarose gel in TBE buffer.

RT-PCR The total plant RNA was extracted according to Logermann et al. [13]. The synthesis of first cDNA chain on DNA-free RNA matrix was carried out using kit \#K1612 (Fermentas) for RT-PCR analysis according to the enclosed instructions. Two parallel reactions in the presence and absence (negative control) of reverse transcriptase were carried out for each sample. We used the described earlier primers and conditions for further amplification of thaumatin II gene fragment. 


\section{Antibacterial activity assay}

Phytopathogen bacteria strains (Pseudomonas syringae 8511, Pectobacterium carotovorum 8982, Xanthomonas campestris 8003b, Agrobacterium tumefaciens 9626) were kindly donated by D. Zabolotny Institute of Microbiology and Virology, NAS of Ukraine.

The extracts of carrot leaves or taproots were prepared by triturating in double volume of $1 \mathrm{M}$ PBS buffer and further several-step centrifugation (10000 rpm for 5-7 min; $15000 \mathrm{rpm}$ for $25 \mathrm{~min} ., 4^{\circ} \mathrm{C}$ ). The obtained plant extracts were tested for antimicrobial activity by modified disk diffusion method. The transgenic plant extracts, the extracts of untransformed plants and PBS buffer were dropped (3-4 times on each Petri dish) on the bacterial lawn. The bacterial cultures were cultivated in thermostat at $+28^{\circ} \mathrm{C}$. The antibacterial activity of the studied extracts was evaluated visually according to the zones of bacteria growth elimination in 24 hours. The experiment was repeated three times.

\section{Antifungal activity assay}

Phytopathogenic fungal culture was isolated from the carrot samples incubated on three solid nutrient media: malt extract agar, potato-dextrose agar and Czapek agar medium at $28 \pm 2{ }^{\circ} \mathrm{C}$ for 14 days [14]. The isolated culture was studied using light microscope MBI-6. The length and width of macro- and microconidia, the size of chlamydospores and diameter of fungal hyphae were measured (x320 enlargement). The isolated plant pathogenic strain was identified as Fusarium solani (Martius) Saccardo [15, 16]. The fungal inoculum $(1 \mathrm{ml})$ of conidia suspension $\left(1 \times 10^{6} / \mathrm{ml}\right)$ was mixed with $100 \mathrm{ml}$ medium and cooled to $30{ }^{\circ} \mathrm{C}$ in order to provide fungi homogenous growth [17]. The extracts of carrot leaves or taproots were prepared by triturating in double volume of buffer containing $100 \mathrm{mM}$ Tris $\mathrm{HCl}, \mathrm{pH}$ 8.0, $5 \mathrm{mM} \mathrm{Na} 2$ EDTA, $100 \mathrm{mM} \mathrm{NaCl}, 10 \mathrm{mM}$ betamercapthethanol with $2.5 \%$ PVP and further several-step centrifugation $(10000 \mathrm{rpm}$ for 5-7 min; $15000 \mathrm{rpm}$ for $\left.25 \mathrm{~min}, 4^{\circ} \mathrm{C}\right)$. The extracts $(100 \mu \mathrm{l})$ were added to $1 \mathrm{~cm}$ diameter lunula and incubated for $24 \mathrm{~h}$ at $4{ }^{\circ} \mathrm{C}$ to enable diffusion of their compounds into agar. Tris-buffer was used as a control. The plates were incubated at $28 \pm 2{ }^{\circ} \mathrm{C}$ for $24-48$ hours with further visual estimation of the zones of fungi growth inhibition.

\section{Plant analysis for osmotic and salt stress tolerance}

The transgenic carrot plants and untransformed (control) ones were cultivated on MS-based media containing $100 \mathrm{mM} \mathrm{NaCl}, 200 \mathrm{mM} \mathrm{NaCl}, 300 \mathrm{mM}$ $\mathrm{NaCl}, 5$ \% PEG 6000 and 7 \% PEG 6000 for 10 days $(\mathrm{NaCl})$ or 15 days (PEG) in order to evaluate the plant salt and osmotic stress tolerance. Meanwhile, we estimated the plant growth parameters and measured their relative growth rate (RGR). RGR was calculated as $\mathrm{RGR}=\left(\operatorname{lnM}_{2}-\ln M_{1}\right) /\left(\mathrm{t}_{2}-\mathrm{t}_{1}\right)$ where $M_{1}$ and $M_{2}$ - yielding plant masses, $\mathrm{t}_{1}$ and $t_{2}$ - harvest times. $[18,19]$.

To measure the photosynthetic pigment content in the stress-effected plants we prepared the extracts by plant triturating in four- fold volume of dimethyl sulfoxide and further incubation in heated bath at $67^{\circ} \mathrm{C}$ for 4 hours. The extract optic density $(649,665$ and $480 \mathrm{~nm}$ ) was measured by spectrofluorimeter and then the pigment content was calculated according to Wellburn et al. [20]

\section{Results and Discussion}

Agrobacterium-mediated transformation of carrot has been reported to provide the opportunity to enhance stress-tolerance and resistance to fungal pathogens by introducing genes encoding chitinases, glucanases, thaumatin-like proteins, osmotin or lysozyme [3,21, 22]. However, we did not manage to find any reports concerning the transgenic celery plants containing the transgenes encoding for pathogen-resistance proteins, though the successfully obtained transgenic celery plants have been reported to carry the introduced reporter or pharmaceutical protein genes [23, 24].

In our study the primary carrot callus clones (Fig. $1, A)$ were moved on regenerative medium with antibiotics in mentioned concentrations in 5-6 weeks after genetic transformation. First regenerates were formed via somatic embryogenesis in 3 months (Fig. 

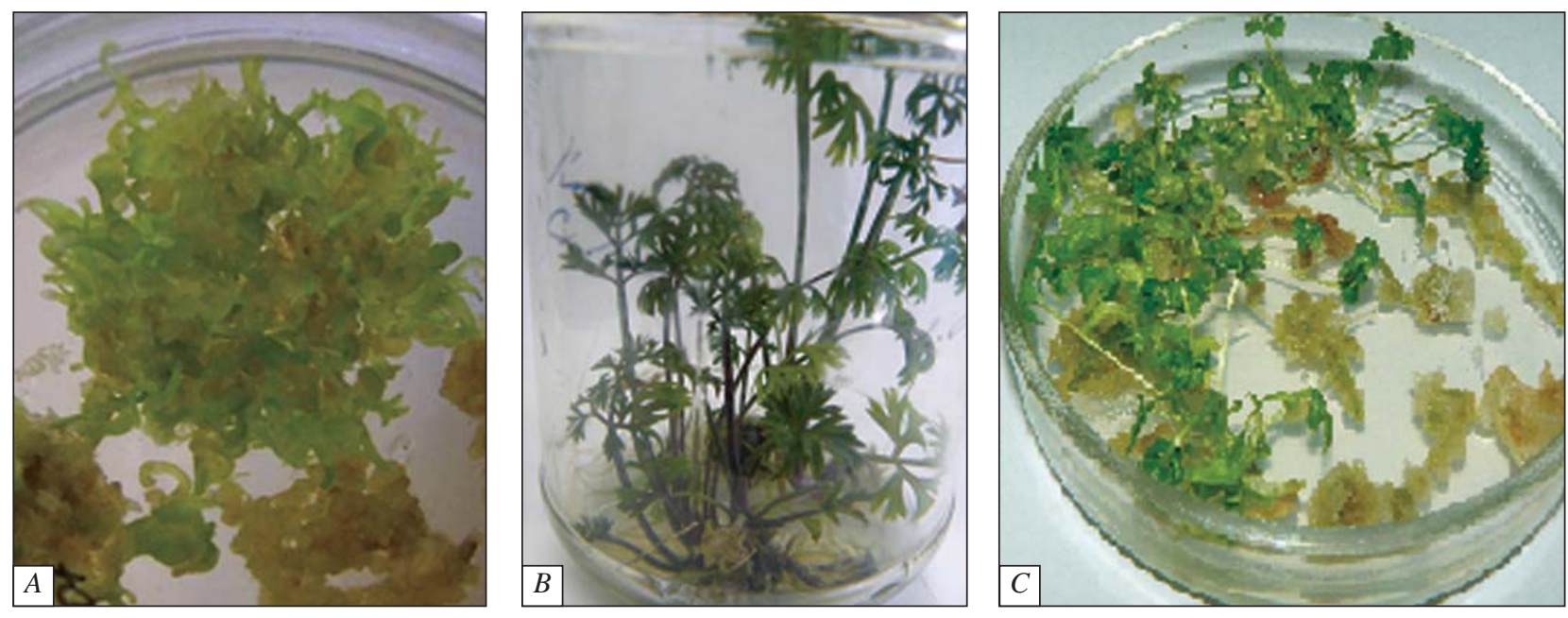

Fig. 1. Formation of the primary carrot callus clones on the selective medium $(A)$, regeneration of carrot $(B)$ and celery $(C)$ kanamycin-resistant plants
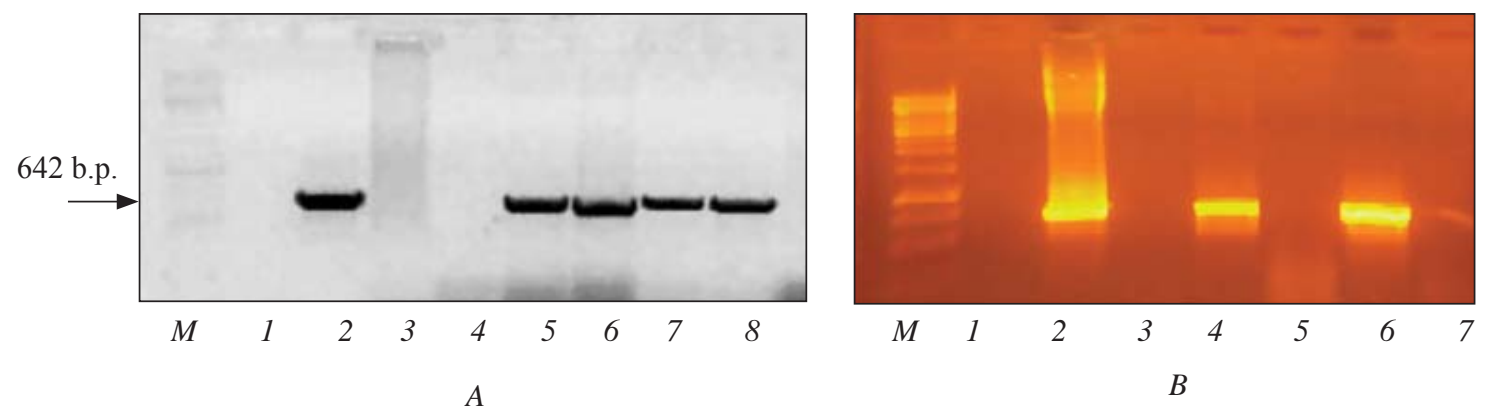

Fig. 2. $P C R$ analysis (thaumatin gene fragment) of the transformed plants $(A)$ : $M-$ DNA marker ladder (1 Kb Plus DNA Ladder, Fermentas), 1 - negative control (no template DNA), 2 - positive control (plasmid DNA pCB171), 3 - negative control (untransformed plant DNA), 4-10 - DNA of the studied plants.

RT-PCR analysis of transgenic carrot plants for proving the thaumatin gene transcription $(B)$ : M - DNA marker ladder (1 Kb Plus DNA Ladder, Fermentas). RT-PCR analysis of transgenic carrot plants for proving the thaumatin gene transcription (B): M - DNA marker ladder (1 Kb Plus DNA Ladder, Fermentas), 1 - negative control (no template DNA), 2 - positive control (plasmid DNA pCB171), 4, 6-plant cDNA (reaction in presence of reverse transcriptase), 5, 7 - plant cDNA (reaction without reverse transcriptase).

$1, B)$. The regeneration of celery plants was observed in 7-8 weeks after obtaining celery callus clones on regenerative medium with selective agents in mentioned concentrations (Fig. 1, C). We managed to obtain up to 4-5 transgenic carrot plants or 2-3 celery ones from each callus clone though we considered them as one regenerated formation due to the same origin. The control untransformed carrot and celery explants were unable to form callus on the media with selective agents.

The frequency of carrot and celery plant genetic transformation is shown in Table 1 as a ratio of the obtained callus clones to the total quantity of the explants. No significant difference of this parameter was observed for diverse carrot cultivars or crop lines but it was observed for celery cultivars probably due to low regenerative capability of Zephyr hypocotyle and leaf explants (results not shown). There was no significant difference of genetic transformation frequency for two Agrobacterium strains used for genetic transformation.

PCR analysis proved the presence of recombinant thaumatin II gene (Fig. 2, A) for $60-100 \%$ of the studied plants and showed the absence of 

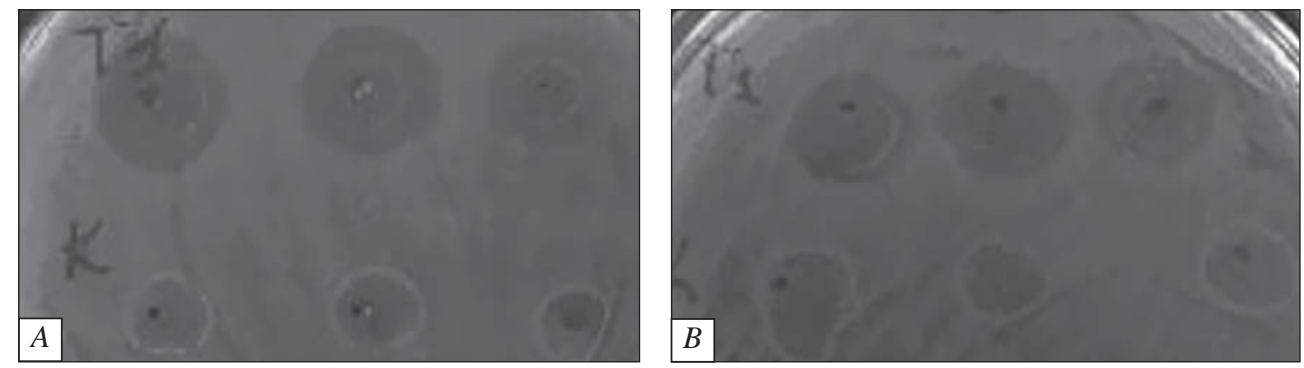

Fig. 3. Antibacterial activity of the studied plant extracts: $A$ - test for the extract activity against Pectobacterium carotovorum 8982, B - test for the extract activity against Xanthomonas campestris $8003 \mathrm{~b}$

agrobacterial contamination for all of them. RTPCR analysis proved the transcription of the target gene (Fig. 2, B).

The expression of the thaumatin gene was resulted in sweet taste properties for such transgenic crops as potato [25], tomato [26], cucumber [27] etc. But we found no taste difference between the obtained transgenic carrot plants and the control untransformed ones. Meanwhile, no alteration of taproot taste has been reported earlier for the carrot plants with proved accumulation and activity of the recombinant thaumatin-like proteins $[3,28]$.

Antifungal activity analysis of the transgenic carrot plant extracts was carried out using F. solani (Mart.) Sacc phytopathogenic strain. We observed no fungal mycelium growth inhibition in our in vitro experiments. At the same time a number of the reports concerning the carrot, tomato and tobacco plants carrying the thaumatin-like III gene sequence showed the increase of plant antifungal activity to Alternaria dauci, A. solani A. petroselini, A. radicini, Botrytis cinerea, Rhizoctonia solani, Sclerotinia sclerotiorum [25-27, 29], the transgenic canola, rice, banana, strawberry plants with the thaumatin-like gene sequences exhibited increasing antifungal activity to S. sclerotiorum, $R$. solani, F. oxysporum, B.cinerea respectively $[30-32,4]$. Here the further antifungal activity analysis of the obtained thaumatin-containing carrot plants seems to be necessary with other phytopathogenic fungi species.

The protein extracts of young transgenic plants inhibited the growth of all the studied phytopathogenic $X$. campestris $8003 \mathrm{~b}, A$. tumefaciens 9626, $P$. carotovorum 8982 , P. syringae 8511 strains even beyond (3-8 $\mathrm{mm}$ ) the measures of drop area. According to Patyka et al. [33] the bacteria growth inhibition zones of 3-8 $\mathrm{mm}$ (12-20 mm diameter) allowed us to consider the studied bacteria strains slightly sensi-

Table 1. Frequency of Agrobacterium-mediated transformation of carrot and celery plants

\begin{tabular}{|c|c|c|c|c|c|}
\hline Cultivar & $\begin{array}{l}\text { Quantity } \\
\text { of explants }\end{array}$ & $\begin{array}{l}\text { Quantity of selective } \\
\text { agent-resistant plants }\end{array}$ & $\begin{array}{c}\text { Frequency } \\
\text { of transformation, \% }\end{array}$ & $\begin{array}{c}\text { Quantity } \\
\text { of PCR-analyzed } \\
\text { plants }\end{array}$ & $\begin{array}{c}\text { Presence } \\
\text { of introduced target } \\
\text { gene sequences } \\
\text { in plants }\end{array}$ \\
\hline \multicolumn{6}{|c|}{ Carrot plants } \\
\hline Konservna-2 & 224 & 67 & 28.6 & 7 & 7 \\
\hline Perfektziya & 110 & 36 & 31.1 & 5 & 5 \\
\hline Dobir-3 & 154 & 44 & 28.5 & 5 & 4 \\
\hline Nantska & 195 & 51 & 26.5 & 6 & 6 \\
\hline \multicolumn{6}{|c|}{ Celery plants } \\
\hline Zephyr (pCB169) & 127 & 13 & 10.2 & 7 & 5 \\
\hline Yablochnyi (pCB169) & 196 & 37 & 18.8 & 10 & 6 \\
\hline Yablochnyi (pCB171) & 216 & 38 & 17.6 & 9 & 8 \\
\hline
\end{tabular}



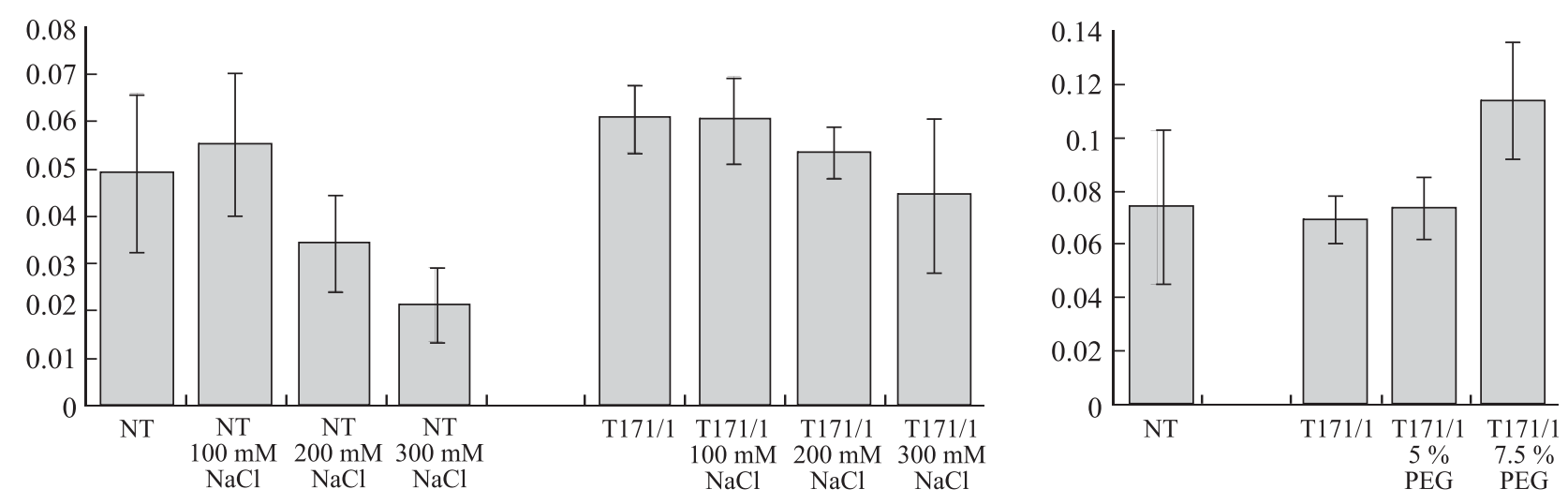

Fig. 4. RGR-test of the studied carrot plants: NT - nontransgenic plants, T171 - transgenic carrot plants with the gene of thaumatin II protein

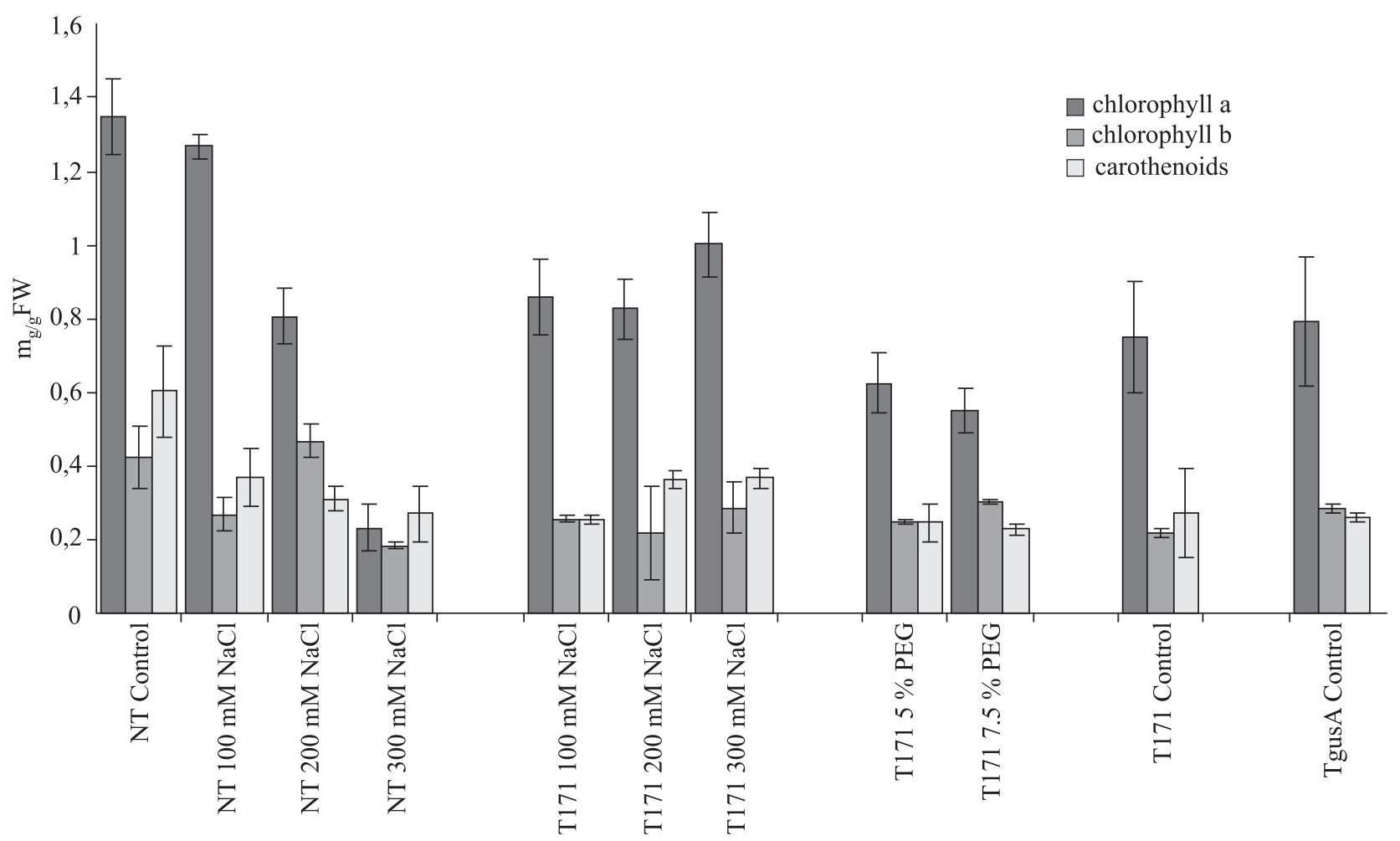

Fig. 5 Photosynthetic pigment content in the studied carrot plants: NT - nontransgenic plants, T171 - transgenic carrot plants with the gene of thaumatin II protein, TgusA - transgenic carrot plants with gusA instead of the thaumatin II gene

tive to the protein extracts of young transgenic plants. At the same time the protein extracts of the transgenic plants with no thaumatin gene that have been cultivated earlier on the selective media did not inhibit the growth of phytopathogenic bacteria but even stimulated $X$. campestris 8982 and A. tumefa- ciens 9626 growth. This fact allowed us to exclude possible effect of the selective antibiotic on the activity of protein extracts of the transgenic plants with the thaumatin II gene. The extract of transgenic callus culture slightly inhibited A. tumefaciens 9626 growth (no more than 3-4 mm) and did not affect the 
growth of any other bacterial strain probably due to the genetic instability of undifferentiated cell culture.

The thaumatin-like proteins are known to have such physiological function as plant protection against osmotic stress conditions. [34] In our study the survival level of the transgenic carrot plants expressing the recombinant thaumatin gene was definitely higher comparing to control untransgenic ones as the latter did not manage to survive on the media with $5 \%, 7.5 \%$ PEG 6000 and were characterized with much lower vital and growth potential on the media with $\mathrm{NaCl}$. Whereas the RGR-test showed no significant changes for the transgenic plants under the salt and osmotic stress effect (Fig. 4), the RGR of the control plants declined twice, their leaves being yellowish, wrapped and less-numbered in the presence of $200-300 \mathrm{mM} \mathrm{NaCl}$. Such biomass decreasing of the untransformed plants may be supplemented by water loss under the salt stress effect. We presume that higher vital level of the transgenic carrot plants under the salt stress effect could indicate a possible protective activity role of the recombinant protein in the transgenic plants. Furthermore, we identified the transgenic carrot plant lines able to develop and generate biomass under osmotic and salt stress conditions.

Photosynthesis is a dominant physiological process thus the limitation of plant growth by stress factors is usually connected with it. The salt stress is considered to cause the decline of chlorophyll and carotenoid content in leaves [35]. Chlorophyll/carotenoid ratio and chlorophyll $a / b$ ratio (normally $3: 1$ ) are known to increase in the early stress-effect period and chlorophyll $a / b$ ratio may decrease in case of the prolonged treatment. So, the measuring of photosynthetic pigments content in the studied plant tissues could allow us to analyze the physiological state of the obtained plants under the salt and osmotic stress effect. Moreover the analysis of photosynthetic pigment content appears quite interesting in view of the possible consequences of using the plasmid vectors which contained the sequence of recombinant thaumatin II fused with plastid targeting transit peptide for the genetic transformation.

Analysis of the chlorophyll content in the nontransgenic plants proved the predicted decline of chlorophyll content in plant tissues in case of salt concentration increasing in the nutritive media. The chlorophyll concentration appeared to decrease greatly so that the chlorophyll a/b ratio was characterized by nearly three-time fall that agrees well with the earlier studies [36,37]. At the same time this parameter did not significantly differ in plant tissues of the obtained transgenic carrots despite the salt concentration varying up to $300 \mathrm{mM} \mathrm{NaCl}$ in the nutritive media (Fig. 5).

This fact might indicate a possible protective role of the recombinant protein in the transgenic plant tissues. The chlorophyll/carotenoid ratio in the obtained transgenic carrot plants demonstrated no significant difference either. The decreased photosynthetic pigment content in the control transgenic plants turned out to be comparable with pigment declining in the tissues of the transgenic plants obtained via genetic transformation using the plasmid vectors with the reporter gene (gusA) in place of thaumatin II one and could be probably explained by Agrobacterium transformation stress effect.

\section{Conclusions}

This work reports the obtaining of the transgenic carrot and celery plants able to express the recombinant gene of thaumatin II protein. No taste difference was observed for the transgenic carrot plants comparing to the untransgenic ones. The extracts of the obtained thaumatin-expressing plants were characterized by antibacterial activity. The RGR-test proved the high vital and growth potential of the transgenic carrot plant lines under osmotic and salt stress conditions, so we may presume the possible protective activity of the recombinant protein in the transgenic carrot plant tissues under salt/osmotic stress effect.

\section{REFERENCES}

1. Parvaiz A, Satyawati S. Salt stress and phytobiochemical responses of plants - a review. Plant Soil Environ. 2008; 54 (3):89-9

2. Rajam MV, Chandola N, Saiprasad Goud P, Singh D, Kashyap V, Choudhary ML, Sihachakr D. Thaumatin gene confers resistance to fungal pathogens as well as tolerance to 
Yu. S. Luchakivska, I. K. Komarnytskii, I. M. Kurchenko et al.

abiotic stresses in transgenic tobacco plants. Biol Plant. 2007; 51(1):135-41.

3. Chen W, Punja Z. Transgenic herbicide- and disease-tolerant carrot (Daucus carota L.) plants obtained through Agrobacterium-mediated transformation. Plant Cell Rep. 2002; 20 (10): 929-35.

4. Schestibratov KA, Dolgov SV. Transgenic strawberry plants expressing a thaumatin II gene demonstrate enhanced resistance to Botrytis cinerea. Sci Hortic. 2005; 106(2): 177-89.

5. Hu X, Reddy AS. Cloning and expression of a PR5-like protein from Arabidopsis: inhibition of fungal growth by bacterially expressed protein. Plant Mol Biol. 1997;34(6):94959.

6. Murashige T, Skoog F. A revised medium for rapid growth and bio assays with tobacco tissue cultures. Physiol Plant. 1962; 15(3):473-97.

7. Komarnytskii I, Shcherbak N, Kishchenko E. Plant genetic transformation by vector with thaumatin II gene. Recent Advances in Plant Genetic Engineering. Kyiv, 2011; 32.

8. Luchakivska Yu, Komarnitskii I, Kuchuk M. Obtaining of transgenic carrot (Daucus carota L.) and celery (Apium graveolens L.) plants expressing the recombinant gene of thaumatin II protein. In Vitro Cell Dev Biol. 2012; 48(4):2069.

9. Gamborg OL, Miller RA, Ojima K. Nutrient requirements of suspension cultures of soybean root cells. Exp Cell Res. 1968;50(1):151-8.

10. Doyle JJ, Doyle JL. Isolation of plant DNA from fresh tissue. Focus. 1990; 12:13-5

11. Draper J, Scott R, Armitage Ph. Plant genetic transformation and gene expression. A laboratory manual. London: Blackwell Scientific Publications Ltd.,1988.

12. Lipp João KH, Brown TA. Enhanced transformation of tomato co-cultivated with Agrobacterium tumefaciens C58C1 Rif(r)::pGSFR1161 in the presence of acetosyringone. Plant Cell Rep. 1993;12(7-8):422-5.

13. Logemann J, Schell J, Willmitzer L. Improved method for the isolation of RNA from plant tissues. Anal Biochem. 1987; 163(1):16-20.

14. Methods of experimental mycology. Kiev: Naukova dumka, 1982; 550 p.

15. Bilai VI. Fusaria. Kyiv, Naukona dumka, 1977; 443 p.

16. Domsch KH, Gams W, Anderson T-H. Compendium of soil fungi. Eching: IHW-Verlag, 2007. 672 p.

17. Klochenko PD, Elanskaya I, Shevchenko T, Sokolova E. Antifungal activity of freshwater cyanobacteria. Algol Stud. 2001; 103:143-9.

18. Hoffmann WA, Poorter H. Avoiding bias in calculations of relative growth rate. Ann Bot. 2002;90(1):37-42.

19. Rees M, Osborne CP, Woodward FI, Hulme SP, Turnbull LA, Taylor SH. Partitioning the components of relative growth rate: how important is plant size variation? Am Nat. 2010; 176(6):E152-61.

20. Wellburn AR. The Spectral determination of chlorophylls A and $\mathrm{B}$, as well as total carotenoids, using various solvents with spectrophotometers of different resolution. J Plant Physiol. 1994; 144(3):307-13.

21. Gilbert MO, Zhang YY, Punja ZK. Introduction and expression of chitinase encoding genes in carrot following Agrobacterium-mediated transformation. In Vitro Cell Dev Boil. Plant. 1996; 32(3):171-8

22. Takaichi $M$, Oeda $K$. Transgenic carrots with enhanced resistance against two major pathogens, Erysiphe heraclei and Alternaria dauci. Plant Sci. 2000;153(2):135-44.

23. Kishchenko E, Shcherbak N, Kyrychuk Y, Kuchuk N. Construction of transgenic plants expressing tuberculosis-specific proteins. Abstracts of the $2 \mathrm{~d}$ meeting of Ukrainian cell biologists organisation. Kyiv, 2007: 32 .

24. Song GQ, Loskutov AV, Sink KC. Highly efficient Agrobacterium tumefaciens-mediated transformation of celery (Apium graveolens L.) through somatic embryogenesis. Plant Cell Tissue Organ Cult. 2007; 88(2):193-200.

25. Witty $M$, Harvey WJ. Sensory evaluation of transgenic Solanum tuberosum producing r-thaumatin II. $N$ Z J Crop Hortic Sci. 1990; 18(2-3):77-80.

26. Bartoszewski G, Niedziela A, Szwacka M, NiemirowiczSzczytt K. Modification of tomato taste in transgenic plants carrying a thaumatin gene from Thaumatococcus daniellii Benth. Plant Breed. 2003; 122(4):347-51.

27. Szwacka M, Krzymowska M, Osuch A, Kowalczyk ME, Malepszy $S$. Variable properties of transgenic cucumber plants containing the thaumatin II gene from Thaumatococcus daniellii. Acta Physiol Plant. 2002;24(2):173-85.

28. Dolgov SV, Lebedev VG, Firsov AP, Taran SA, Tjukavin GB. Expression of thaumatin II gene in horticultural crops. Genetics and Breeding for Crop Quality and Resistance. 1999; 165-72.

29. Safavi K,Zareie R, Tabatabaie BES. Expression of TLP-3 gene without signal peptide in tobacco plants using Agrobacterium mediated transformation. Afr J Biotechnol. 2011; 10(24):4816-22

30. Zamani A, Motallebi M, Jonoubi P, Ghafarian-Nia NS, Zamani MR. Heterologous expression of the Secale cereale thaumatin-like protein in transgenic canola plants enhances resistance to stem rot disease. Iran J Biotechnol. 2012;10 (2):87-95.

31. Datta K, Velazhahan R, Oliva N, Ona I, Mew T, Khush GS, Muthukrishnan S, Datta SK. Over-expression of the cloned rice thaumatin-like protein $(P R-5)$ gene in transgenic rice plants enhances environmental friendly resistance to Rhizoctonia causing sheath blight disease. Theor Appl Genet. 1999; 98(6-7):1138-45.

32. Mahdavi F, Sariah M, Maziah M. Expression of rice thaumatin-like protein gene in transgenic banana plants enhances resistance to fusarium wilt. Appl Biochem Biotechnol. 2012;166(4):1008-19.

33. Patyka V, Gnatyuk T, Zhitkevych N, Aleksaev O. Sensitivity to pesticides of the number of representatives of the bacterial microbiota soybean. Nauk Zapys Ternop Nats Ped Univer, (Ser. Biol). 2014; 3 (60): 153-5 
Construction and analysis of the transgenic carrot and celery plants expressing the recombinant thaumatin II protein

34. Kitajima S, Sato F. Plant pathogenesis-related proteins: molecular mechanisms of gene expression and protein function. J Biochem. 1999;125(1):1-8.

35. Parida $A K$, Das $A B$. Salt tolerance and salinity effects on plants: a review. Ecotoxicol Environ Saf. 2005;60(3):324-49.

36. Mane AV, Karadge BA, Samant JS. Salinity induced changes in photosynthetic pigments and polyphenols of Cymbopogon Nardus (L.) Rendle J Chem Pharm Res. 2010;2(3):338-47.

37. Mehta P, Jajoo A, Mathur S, Bharti S. Chlorophyll a fluorescence study revealing effects of high salt stress on Photosystem II in wheat leaves. Plant Physiol Biochem. 2010; 48 (1):16-20.

\section{Отримання та аналіз трансгенних рослин моркви та селери, здатних експресувати рекомбінантний білок тауматин II}

Ю. С. Лучаківська, І. К. Комарницький, І. М. Курченко, О. М. Юр'єва, Н. В. Житкевич, М. В. Кучук

Мета Отримати трансгенні рослини моркви та селери, що експресують рекомбінантний тауматин II, з метою підвищення стресостійкості цих культур. Методи. Для отримання трансгеннихрослинпроводилиAgrobacterium-опосередковану трансформацію. Присутність та транскрипцію трансгенів підтверджували за допомогою ПЛР та ЗТ-ПЛР аналізів. Визначали стійкість отриманих рослин до біотичних стресфакторів (аналіз антибактеріальної/антифунгальної активності in vitro) та до дії сольового/осмотичного стресу (тест на

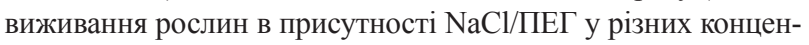
траціях). Результати. Трансгенні рослини моркви та селери, що експресують ген тауматину II (транскрипцію підтверджено для 60-100 \%) було отримано шляхом агро бактеріальної трансформації. Екстракти трансгенних рослин моркви інгібували ріст досліджуваних штамів фітопатогенних бактерій, але не проявляли антифунгальної активності. Рівень виживання трансгенних рослин при абіотичному стресі був значно вищим у порівнянні 3 нетрансгенними рослинами. Аналіз вмісту фотосинтетичних пігментів не показав достовірної різниці показників для трансгенних рослин при сольовому стресі, що може вказувати на можливу захисну активність рекомбінантного білка. Висновки. Отримані у наших дослідженнях трансгенні рослини селери та моркви, що експресують рекомбінантний тауматин II, характеризувались антибак- теріальною активністю та підвищеною стійкістю до сольового та осмотичного стресу.

Кл юч о в і с л о в а: морква, селера, тауматин II, Agrobacterium-опосередкована трансформація, стресостійкість.

\section{Получение и анализ трансгенных растений моркови и сельдерея, способных экспрессировать рекомбинантный белок тауматин II}

Ю. С. Лучакивская, И. К. Комарницкий, И. Н. Курченко, Е. М. Юрьева, Н. В. Житкевич, Н. В. Кучук

Цель. Получить трансгенные растения моркови и сельдерея экспрессирующие рекомбинантный тауматин II с целью повышения стресс-устойчивости этих культур. Методы Для получения трансгенных растений проводили Agrobacteriumопосредованную трансформацию. Присутствие и транскрипцию трансгенов подтверждали с помощью ПЦР и ОТПЦР анализов. Определяли устойчивость полученных растений к биотическим стресс-факторам (анализ антибактериальной/антифунгальной активности in vitro) и к действию солевого/ осмотического стресса (тест на выживывание растений в присутствии $\mathrm{NaCl} /$ ПЭГ в различных концентрациях). Результаты Трансгенные растения моркови и сельдерея, экспрессирующие ген тауматина II (транскрипция подтверждена для 60-100 \%) были получены путем агробактериальной трансформации. Экстракты трансгенных растений моркови ингибировали рост исследуемых штаммов фитопатогенных бактерий, но не проявляли антифунгальной активности. Уровень выживания трансгенных растений при абиотическом стрессе был значительно выше по сравнению с нетрансгенными растениями. Анализ содержания фотосинтетических пигментов не показал достоверной разницы показателей для трансгенных растений при солевом стрессе, что может указывать на возможную защитную активность рекомбинантного белка. Выводы. Полученные в наших исследованиях трансгенные растения сельдерея и моркови, экспрессирующие рекомбинантный тауматин II, характеризовались антибактериальной активностью и повышенной устойчивостью к солевому и осмотическому стрессу.

Кл юч е в ы е с л о в а: морковь, сельдерей, тауматин, Agrobacterium-опосредованная трансформация, стресс-устойчивость.

Received 03.11.2014 